\title{
The structural relationship on sport values and continuous participation intention of the dance for all participants based on the 4 experience economy theory
}

\author{
Jeoung-hak Lee \& Sun-young Lim* \\ KyungHee University
}

\begin{abstract}
[Purpose] The purpose of this study was to examine the structural relationship between the sport values and continuous participation intention of the dance for all participants based on the 4 experience economy theory. [Methods] Frequency analysis, correlation analysis, confirmatory factor analysis and structural equation modeling using SPSS 21.0 and AMOS 18.0 were conducted to analyze the survey materials. [Results] First, the entertainment experience was a significant effect on all factors of sports value. Second, educational experience was a significant effect on all factors except sports entertainment value. Third, escapist experiences have a significant effect on all factors except physical value. Fourth, aesthetic experience has a significant effect on all factors of sports value. Fifth, social value and entertainment value was a significant influence on the continuous participation intention. Sixth, entertainment experience and aesthetic experience was a significant influence on the continuous participation intention. [Conclusions] Through these study results, it was confirmed that 4 experience, sport values and continuous participation intention of dance for all participants had a significant influence on each other.
\end{abstract}

Key words: 4 Experience economy theory, Dance for all, Sport values, Continuous participation intention

\section{서 론}

\section{연구의 필요성 및 목적}

최근 매스미디어를 통해 이슈가 되고 있는 '욜로', '을로 족' 은 '인생은 한번 뿐이다'를 뜻하는 You Only Live Once의 앞 글자를 딴 신조어이다. 이는 자신의 현재 행복 을 가장 중시하여 소비하는 라이프스타일로써 젊은 층을 시작으로 청소년, 중·노년층까지 그 범위가 확대되어 새 로운 문화 트렌드로 자리 잡고 있다. 이러한 사회적 변화

논문 투고일 : 2019. 01. 30.

논문 수정일 : 2020. 03. 05.

게재 확정일 : 2020. 05. 25.

* 교신저자 : 임선영(sy870413@hanmail.net).
는 여가생활의 참여기회 증대 뿐 아니라 단순한 휴식보다 건강과 삶의 질을 높이고자 하는 삶에 대한 패러다임의 변화를 의미한다(Seo, 2012).

이처럼 우리나라는 지속적인 경제성장과 더불어 주 5 일 근무의 보편화로 인해 개인의 잉여시간이 증대되면서 건강을 증진시키고 스트레스의 해소 및 삶의 만족도를 높 여주는 여가활동에 대한 관심이 높아지고 있다(Lee, 2014).

Sports \& Tourism(2018)에 따르면 2017년 생활체 육 종목 가운데 동호인 수가 많은 순서는 수영 (11.3\%), 축구 $(11 \%)$, 보디빌딩 $(10.3 \%)$, 골프 $(10.1 \%)$, 배드민턴 $(8.8 \%)$, 생활체조 $(7.3 \%)$ 로 나타났으나 생활체조 종목 에 에어로빅 동호인(4.7\%)을 ‘리듬을 즐기는 동호인'의 
개념으로 포함시키면 가장 많은 수의 동호인이 여가시간 을 활용하여 생활무용을 즐긴다는 흥미로운 사실을 발견 하게 된다(Lim, 2018; Yoo, 2010).

생활무용은 '사회무용', '대중무용'이라는 말과 함께 모 든 사람을 위한 무용(Dance for all)의 개념으로 개인의 건강 증진과 미적 교육, 삶의 질을 향상시킴으로써 복지 증진을 목적으로 행해지는 신체활동의 총체이다(Lee, 2001; Lee, 2009). 또한 남녀노소 누구나 쉽게 즐길 수 있는 유용한 여가활동으로 현대인에게 스트레스 해소의 기회를 제공해주며 건강한 체력, 아름다움의 증진, 자신 감, 자존감 및 타인으로부터의 인정 등 개인의 삶의 질을 향상시킬 수 있다는 점에서 매우 가치 있는 신체활동으로 인정받고 있다. 최근에는 생활무용과 관련된 다양한 뉴미 디어 플랫폼 콘텐츠들이 제작되고 대중들에게 노출됨에 따라 여성소비자의 참여가 절대적이었던 과거와 달리 남 성소비자들이 참여하는 시장 확대도 점차 증가되는 추세 이다(Kim \& Kang, 2007; Park, 2013; Shin \& Park, 2007; Youm, 2008).

이처럼 생활무용은 더 이상 소수의 부유층과 전공자들 만을 위한 예술로 존재하지 않으며, 눈으로만 감상하는 관람형 예술에서 그치는 것이 아닌 몸으로 직접 경험하는 참여형 예술 형태로 변화하고 있다 (Park \& Hae, 2016). 그렇다면 무엇이 이들을 생활무용에 참여하게 하 고 몰입하게 하며 지속하게 만드는 것일까?

이러한 현상은 Pine \& Gilmore(1998)가 제시한 체험 경제(experience economy)의 관점에서 설명이 가능하 다. 체험경제이론은 제품의 효용이 아닌 소비자가 느끼는 체험의 중요성을 강조한다(Hwang \& Park, 2016). 여 기서 말하는 체험이란 특별한 사건에서 발생되는 소비자 의 반응으로 그것은 오감(미각, 시각, 청각, 후각, 피부감 각)으로 인지하게 된다(Schmitt, 1999). 오감을 통해 인 지된 체험은 소비자들로 하여금 내·외적 욕구 충족과 긍 정적 감정을 느끼게 하여 자발적이고 물리적인 소비자의 참여를 유도하게 되고 이는 기존 소비 의사결정 모델로는 설명할 수 없는 특유의 소비 행위를 경험하게 된다는 것 이다(Hong, 2010).

Pine \& Gilmore(1998)의 체험경제이론에 따르면, 체 험은 단순히 감각적인 측면 뿐 아니라 오락적 측면, 교육 적 측면, 일탈적 측면, 미적 측면을 포괄하는 광범위한 개
념이기 때문에 이를 모두 반영할 수 있는 상품이 개발될 때 비로소 기존의 상품들과 차별화되고 경쟁력 있는 최상 의 체험 상품이 된다고 강조하였다. 따라서 체험경제이론 의 세부체험 요소 $(4 \mathrm{Es})$ 를 이해하고 적용하는 것은 제품 개발 실무자에게 매우 중요한 일이라고 할 수 있다(Park \& Cha, 2007).

오락적 체험은 재미, 흥미 등 인간의 감정을 즐겁게 만 들거나 이끌어낼 수 있는 요소들을 총괄적으로 내포하고 있는 개념으로 프로 스포츠나 무용공연 등의 관람을 통해 프로 선수들의 인상적인 경기 또는 무용수들의 예술적 몸 짓에 매료되는 상황들이 이에 해당된다(Ha, 2009). 교 육적 체험은 평소에 알지 못했던 지식 또는 정보를 새롭 게 배우려는 갈망이라고 정의하고 있으며, 소비자들은 어 떤 행사 또는 이벤트에 머무는 동안 새롭게 무언가를 배 우겠다는 욕망이 강하기 때문에 적극적인 참여 및 높은 몰입도를 보여준다. 테니스 강좌나 생활무용 수업을 수강 하는 경험 등이 교육적 체험의 대표적인 예라고 할 수 있 다(Kwon \& Kim, 2018). 일탈적 체험은 소비자가 의도 적으로 집중하기 보다는 자연스럽게 몰입의 경지에 이르 는 경험으로 예를 들면 에베레스트 등정에 참여한 소비자 들이 자연의 신비를 직접 경험하고 일상에 지친 심신을 힐링하며 일상생활에서 벗어나는 등의 느낌을 받는 것이 이에 해당된다. 이러한 일탈적 체험의 경험은 소비자로 하여금 적극적인 태도로 일상과 단절된 제 3 의 공간(the third place)를 찾으려는 옥구를 충족시킬 수 있다(Pine \& Gilmore, 1998). 미적체험은 소비자의 주변을 둘러싸 고 있는 환경에 대한 해석이다(Hosany \& Witham, 2010). 즉, 제공된 이벤트나 주변 환경에 소비자 스스로 가 몰입하여 주어진 공간이나 환경 내에 지속적으로 존재 하고 체험하고자 하는 것을 의미한다(Pine \& Gilmore, 1998). 그 예로는 가을 단풍을 보기 위한 산행과 같은 활 동이나 불꽃축제와 같이 평소에 경험하지 못한 아름다운 광경에 몰입하는 것이 라고 할 수 있다(Hwang \& Park, 2016).

이와 같이 세부체험 요소(4Es)를 복합적으로 활용하 여 총체적 체험을 경험하도록 유도하고 체험의 가치를 극 대화시키고자 한 체험경제이론은 분석적이고 계량적이 며 언어중심적인 전통적 마케팅의 방법론과는 달리 이성 적이면서도 감성적인 소비의 두 측면 모두를 고려하는 다 
각적인 형태의 접근 방법이라 할 수 있다. 때문에 최근에 는 소비자의 체험을 중심으로 한 소비형태 분석과 같은 연구들이 활발히 진행되고 있다.

이와 관련해 $\operatorname{Kim}(2017), \operatorname{Kwon}(2014)$, Lee et al.,(2017), Seo(2012), Shim(2013), Shim(2017)은 체험경제이론을 적용한 연구들을 통해 해양레저 및 워터 파크 운영에 대한 효율적인 마케팅 전략을 제시하고 있으 며, Ji et al., (2013)은 긍정적 체험의 경우 대상에 대한 높은 선호도와 충성도를 가지게 하지만 반대로 부정적 체 험은 기피현상과 부정적 구전효과를 가져온다고 하였다. 또한 Kim \& Sung(1996), Kint \& Weiss(1987), Han et al., (2010)은 스포츠 활동을 통해 경험하는 즐거움, 좋아함, 흥미 등의 긍정적 정서반응이 지속적 참여를 결 정짓는 핵심 동기요인이며, 스포츠 수행 중 체험을 통해 나타나는 요소 또한 지속적인 운동참가를 이끌어내는 중 요 요인임을 밝힌 바 있다.

더욱이 스포츠나 무용에 관련된 상품은 일반 용품 및 의류 등과는 다르게 '활동'이라는 개성이 더욱 강조되기 때문에 소비자들의 구매행동에 있어 체험의 요소는 더욱 중요하다고 할 수 있다(Chung \& Yu, 2006).

이러한 맥락에서 신체를 매개로 표현하는 언어로써 수 많은 감성과 정서를 경험할 수 있는 유일무이한 장르인 생활무용은 본질적으로 경험적 특성을 강하게 가지고 있 기 때문에 생활무용 분야에서의 체험 유형과 그에 따른 가치에의 접근은 생활무용 전반의 발전을 위해 필수적이 라 할 수 있다(Holbrook \& Hirshman, 1982). 또한 생 활무용은 참여자의 자발적인 참여를 전제로 직접적인 신 체의 체험을 목적으로 이루어지는 지속적 활동이기 때문 에 체험경제이론을 적용하기에 적합하다 $(\mathrm{Lim}, 2002)$. 이는 소비자의 구매행동을 증가시키기 위한 수단으로 단 발성 체험에 국한된 타 분야와의 가장 큰 차이점이기도 하다. 따라서 생활무용이 가지는 경험적 특성을 파악하여 경험의 차별화를 이끌어 낼 수 있는 생활무용참여자의 소 비행동 모델이 제시될 필요가 있다.

한편, Leonard(1980)는 현대사회에서의 생활체육 및 스포츠는 그 사회의 지배적인 가치 및 태도를 적용하는 축소판이며 이는 특정사회가 가지고 있는 규범과 역할을 수행하기 위한 최선의 방법을 제공한다고 하였다. 따라서 생활체육 및 스포츠에 지속적인 관심을 가지거나 참여하
는 사람의 경우, 생활체육 및 스포츠 자체에 대한 긍정적 인 이미지를 형성하게 되는 것이다(Ahn, 1999; Kim, 2012; Shim \& Oh, 2014). 이는 생활무용 참여를 통해 경험하게 되는 체험의 요소가 스포츠가치관 형성에 있어 긍정적 영향을 미친다는 이론적 근거로 제시될 수 있다 (Sung, 2016).

즉, 생활무용의 주된 목적이 남녀노소 구분 없이 건전 한 여가생활을 통해 올바른 가치관을 확립하고 신체·정 서·사회적으로 조화로운 발달을 이루며 삶의 질 향상과 더불어 '평생체육'으로써의 발판을 마련해 주는 것이라는 점은 체험경제이론의 세부체험 요소 $(4 \mathrm{Es})$ 가 생활무용참 여자의 바람직한 스포츠가치관 형성과 지속적 참여의도 에 긍정적 영향을 미치는 중요 요인으로 작용할 수 있음 을 유추할 수 있다.

그럼에도 불구하고 지금까지 연구된 연구들은 주로 관 광산업과 해양레저스포츠 분야에 편중 현상을 보이고 있 어 생활무용을 배경으로 체험경제이론을 적용한 연구는 매우 미비한 실정이다. 때문에 생활무용 활성화 방안에 중요한 학술적 자료로 활용될 수 있는 체험경제이론과 관 련된 연구는 전혀 이루어지지 못하고 있다.

따라서 본 연구는 Pine \& Gilmore(1998)의 체험경제 이론에 근거하여 체험의 요소를 오락적 체험, 교육적 체 험, 일탈적 체험, 미적 체험으로 분류하고 각각의 체험 요 소와 생활무용참여자의 스포츠가치관 및 지속적 참여의 도간의 영향관계를 규명하고자 한다. 이를 통해 생활무용 분야의 부족한 지식체계 형성과 더불어 효율적인 생활무 용 프로그램 개발 및 운영전략을 위한 학문적 기초자료를 제공하는 데 그 목적이 있다. 이는 더 나아가 생활무용의 활성화 및 잠재적인 생활무용 인구의 저변확대를 위한 방 안 강구에 기여할 것으로 사료된다.

\section{생활무용참여자의 체험요인과 스포츠가치관의 관계}

체험요인과 스포츠가치관에 관한 연구를 진행한 Lee(2011)는 스포츠가치관이 높을수록 체험에 대한 인 식이 긍정적으로 나타난다고 밝혔다.

이를 보다 세부적으로 살펴보면, 오락적 체험은 참여 를 통해 기분 전환의 상태를 자극하거나 촉진하여 만들어 내는 것으로 참여자 스스로가 직접 참여하거나 다른 사람 
의 참여 모습을 보는 것이 유쾌하고 흥미롭다라는 개념의 변수로 Park(2019)은 프로야구 관람체험과 지각된 가치 의 관계성을 파악하는 연구를 통해 오락적 체험, 교육적 체험, 일탈적 체험, 미적 체험 모두 사회적 가치에 유의한 영향을 미친다고 밝혔다. $\operatorname{Kim}(2015)$ 은 학교스포츠클럽 농구 종목에서 학생들의 동기를 유발하는 중요 요인은 즐 거움, 재미 등과 같은 오락적 체험이라고 제시하였으며, 이를 통해 학생들은 기술 훈련과 경기에 적극적으로 참여 하게 되고 자신도 모르는 사이에 체력이 향상되는 등의 신체적 가치가 높아진다고 하였다. 또한 Shim \& $\mathrm{Oh}$ (2014)은 방과 후 스포츠 활동 참여를 통해 오락적 체 험을 경험한 학생들의 경우, 삶의 피로회복 및 스트레스 를 해소 등 오락적 가치관에 긍정적 효과를 나타낸다고 보고한 바 있다.

교육적 체험은 참된 정보를 알려주고 지식이나 능력을 향상시켜주는 체험 형태로 개인의 적극적인 참여가 개입 되어야 하는 변수이다. 이에 $\operatorname{Kim}(2012)$ 은 동계 레저스 포츠의 교육적 체험이 사회적 가치에 유의한 영향을 미친 다고 밝힌 바 있으며, Sung(2016)는 학교스포츠클럽 활 동을 통해 학생들은 습득한 운동 기술을 값지게 생각하는 교육적 체험을 경험하게 되고 이는 신체적 가치에 긍정적 인 영향을 미친다고 하였다. 또한 $\mathrm{Kim}(2011)$ 은 중년 여 성 휘트니스 클럽 회원들의 교육적 체험은 개인이 보유한 기술 수준과 도전이 적정 수준에서 균형을 이룰 때 경험 하게 되며 이로 하여금 신체적 가치를 높일 수 있으며, 이 러한 교육적 체험의 경험이 신체적 가치를 예측하는데 가 장 중요한 변인임을 강조하였으며, Myoung(2017) 역시 체험경제이론을 이용한 템플스테이 참가자의 지각된 가 치에 대한 연구를 통해 교육적 체험이 오락적 가치, 사회 적 가치, 품성적 가치에 영향을 미친다는 연구 결과를 제 시한 바 있다.

일탈적 체험은 참여자의 적극적인 참여를 통해 제공된 가상현실에 완전히 몰입된 상태를 나타내는 변수로 이와 관련한 연구에서 Sung(2016)는 학교스포츠클럽 활동에 참여하는 중학생들이 다른 세상을 경험한 듯한 일탈적 체 험을 경험하게 되면 사회적 가치는 높게 나타난다고 하였 으며, Myoung(2017)는 템플스테이에 참가한 참여자를 대상으로 한 연구에서 일탈적 체험을 경험한 참여자는 대 인관계가 보다 깊어지는 사회적 가치, 자신이 특별한 사
람이라고 느끼는 품성적 가치, 즐거운 시간을 보내고 좋 은 기분을 느끼는 오락적 가치에 긍정적 영향을 미친다고 언급했다. 또한 $\operatorname{Kim}(2001)$ 은 댄스스포츠를 통한 몰입경 험 연구를 통해 댄스 스포츠의 참여자들은 춤을 추면서 음악과 파트너에 대해 자연스럽게 몰입하게 되고 그 순간 일상생활과 분리되는 일탈적 체험을 경험하게 되며, 이러 한 경험은 신체의 능력을 극대화시키고 신체의 한계를 극 복하는 신체적 가치에 영향을 미친다는 결과를 보고했다. 이와 같은 맥락에서 Song \& Lee(2015) 역시 템플스테 이 체험과 방문객 행 동의도와의 관계성 연구를 통해 템플 스테이 방문객들은 복잡한 일상생활로부터 벗어나려는 욕구가 강하게 나타나는데 이러한 욕구를 템플스테이 참 가라는 일탈적 체험을 통해 충족함으로써 즐거움이라는 오락적 가치와 마음의 평안함이라는 품성적 가치의 수준 을 보다 높일 수 있다고 주장했다.

미적체험은 참여자가 심미적 특성을 갖춘 요소를 체험 하고 감상하는 것을 의미하는 변수로 참여자가 미적 체험 을 경험하게 되면 체험에 대한 긍정적 반응도 증가하게 된다(Kwon \& Kim, 2018). 이에 $\mathrm{Seo}(2012)$ 는 관광이 라는 체험은 관광객들로 하여금 관광지에 대한 감성적인 사고를 유도하고 다양한 연상을 북돋아주며, 관광객과 관 광지를 하나로 연결시키는 역할을 한다고 제시함과 동시 에 관광에 대한 긍정적 가치 및 유대관계를 형성하는데 있어 미적체험이 중요한 역할을 수행한다고 언급하였다. $\operatorname{Lim}$ (2010)에 따르면 야외 레저스포츠는 자연의 신비감 등의 미적 체험을 직접 경험할 수 있는 여가스포츠로써 복잡한 도심에서 찾을 수 없는 삶의 의미를 찾기 위한 사 회적 가치를 수반하고 있다고 하였으며, Kwon(2019)은 태권도 회전발차기 실천자의 미적 체험 연구를 통해 회전 발차기 수행을 위해서는 근력, 순발력, 도약력 등과 같은 체력이 요구되어짐에 따라 수행자는 이러한 신체적 가치 의 수준을 높이고자 노력하는 과정에서 미적 체험을 더욱 강하게 경험한다는 결과를 보고한 바 있다. 또한 Lee(2007)는 스포츠 수행자가 신체적 가치를 높여 보다 난이도 높은 기술이나 탁월한 기법을 표출할 때 미적 체 험 요소가 높아진다고 주장하였으며, Kwon(2014)은 해 양스포츠가 다채로운 해양 환경과 함께 이루어지는 스포 츠 활동이기 때문에 참여자들은 환경에 대한 지각과 시각 적인 미적 체험을 강하게 경험하게 되고 이는 자기만족, 
생활만족 등과 같은 품성적 가치에 긍정적 영향을 미친다 고 밝혔다. 한편, Whang \& Hwang \& Na(2014)은 스 포츠경기 관람객들이 스포츠경기에서 지각하는 경기심 미성, 선수의 신체적 매력성의 미적체험 요소가 관람객들 로 하여금 흥미진진함, 즐거움과 같은 오락적 가치를 높 인다고 하였고 Song \& Lee(2015)은 템플스테이 방문객 들이 오락적, 일탈적, 미적 체험 요소를 높게 인식할수록 템플스테이에 대한 즐거움이 증가함을 제시한 바 있다.

이러한 선행연구 결과를 토대로 본 연구에서는 다음과 같은 연구 가설을 설정하였다.

$\mathrm{H1}$ : 체험경제이론에 따른 생활무용참여자의 체험 요인은 스포츠 가치관에 유의한 영향을 미칠 것 이다.

H1-1: 체험경제이론의 오락적 체험은 스포츠가치관의 구성요인 중 사회적 가치에 영향을 미칠 것이다.

$\mathrm{H} 1-2$ : 체험경제이론의 오락적 체험은 스포츠가치관의 구성요인 중 신체적 가치에 영향을 미칠 것이다.

H1-3: 체험경제이론의 오락적 체험은 스포츠가치관의 구성요인 중 품성적 가치에 영향을 미칠 것이다.

H1-4: 체험경제이론의 오락적 체험은 스포츠가치관의 구성요인 중 오락적 가치에 영향을 미칠 것이다.

H1-5: 체험경제이론의 교육적 체험은 스포츠가치관의 구성요인 중 사회적 가치에 영향을 미칠 것이다.

H1-6: 체험경제이론의 교육적 체험은 스포츠가치관의 구성요인 중 신체적 가치에 영향을 미칠 것이다.

H1-7: 체험경제이론의 교육적 체험은 스포츠가치관의 구성요인 중 품성적 가치에 영향을 미칠 것이다.

H1-8: 체험경제이론의 교육적 체험은 스포츠가치관의 구성요인 중 오락적 가치에 영향을 미칠 것이다.

H1-9: 체험경제이론의 일탈적 체험은 스포츠가치관의 구성요인 중 사회적 가치에 영향을 미칠 것이다. H1-10: 체험경제이론의 일탈적 체험은 스포츠가치관의 구성요인 중 신체적 가치에 영향을 미칠 것이다. H1-11: 체험경제이론의 일탈적 체험은 스포츠가치관의 구성요인 중 품성적 가치에 영향을 미칠 것이다. $\mathrm{H} 1-12$ : 체험경제이론의 일탈적 체험은 스포츠가치관의 구성요인 중 오락적 가치에 영향을 미칠 것이다. H1-13: 체험경제이론의 미적 체험은 스포츠가치관의
구성요인 중 사회적 가치에 영향을 미칠 것이다. H1-14: 체험경제이론의 미적 체험은 스포츠가치관의 구성요인 중 품성적 가치에 영향을 미칠 것이다. H1-15: 체험경제이론의 미적 체험은 스포츠가치관의 구성요인 중 신체적 가치에 영향을 미칠 것이다. H1-16: 체험경제이론의 미적 체험은 스포츠가치관의 구성요인 중 오락적 가치에 영향을 미칠 것이다.

\section{생활무용참여자의 스포츠가치관과 지속적 참여의도의 관계}

McDowell(1984)은 개인의 가치관에 따라 레저스포 츠에 대한 인식이나 태도가 변화한다고 주장하였으며, Jung(1997)은 운동에 대한 내적 동기의 태도, 기대감 등 이 운동지속 행동에 변화를 주는 원인으로 작용한다고 보 고하였다. 이러한 선행연구의 결과는 스포츠가치관과 운 동지속의도의 관계성을 이론적으로 뒷받침해 주고 있다.

이와 관련한 연구들을 살펴보면, Jung et al.,(2012) 은 대학 운동선수가 인식한 지도자 리더십 유형과 스포츠 가치관 및 운동지속수행의 관계에 대한 연구를 통해 사회 적 가치, 품성적 가치, 오락적 가치가 운동지속수행에 유 의한 영향을 미친다는 결론을 제시한 바 있으며, Choi(2013) 역시 대학생의 사회적 가치, 품성적 가치, 오락적 가치가 스포츠 참가정도에 긍정적 영향을 미친다 고 하였다.

여기서 말하는 사회적 가치는 스포츠가 건전한 사회성 을 함양시켜주는 수단으로 작용됨을 의미하는 개념이며, 신체적 가치는 스포츠 활동을 매개로 신체적 효과성을 추 구하는 개념의 가치관이다. 품성적 가치는 스포츠 활동을 통해 선의의 경쟁 원리를 익히고 나아가 규칙과 질서의식 의 준수하는 태도를 말하며, 오락적 가치는 스포츠 활동 이 스포츠의 본질인 놀이와 유희적 기능을 발회한다고 보 는 시각이다(Oh, 2000). 이에 Sung(2016)는 스포츠 활 동을 통해 스포츠가치관이 형성되고 이는 참여의도에 긍 정적 영향을 미친다는 연구결과를 보고한 바 있다.

이러한 선행연구 결과를 토대로 본 연구에서는 다음과 같은 연구 가설을 설정하였다.

$\mathrm{H} 2$ : 생활무용참여자의 스포츠가치관은 지속적 참여 의도에 유의한 영향을 미칠 것이다. 
H2-1: 스포츠가치관의 사회적 가치는 지속적 참여의 도에 영향을 미칠 것이다.

H2-2: 스포츠가치관의 신체적 가치는 지속적 참여의 도에 영향을 미칠 것이다.

H2-3: 스포츠가치관의 품성적 가치는 지속적 참여의 도에 영향을 미칠 것이다.

$\mathrm{H} 2-4$ : 스포츠가치관의 오락적 가치는 지속적 참여의 도에 영향을 미칠 것이다.

\section{생활무용참여자의 체험요인과 지속적 참여의도의 관계}

You \&Jeon(2016)은 체험을 통해 얻게 되는 기억이 경험의 공유를 통해 향후 지속적 참여의도에 영향을 준다 고 주장하였다.

이와 관련한 연구에서 Hosany \& Witham(2010)는 크루즈 탑승객의 오락적 체험은 만족도 및 재방문과 추천 의사를 형성함에 있어서 중요한 역할을 한다고 하였으며, You \& Park \& Lee(2015)는 '양양송이 축제'에 참가한 관람객들의 오락적 체험이 높을수록 축제에 대한 높은 만 족도를 나타낸다고 밝혔다. Song et al,..(2015)는 사찰 을 방문하는 관광객의 교육적 체험이 전반적인 만족도를 높여 지속적 방문의도에도 중요한 요인으로 작용한다고 하였으며, Lee \& Sun(2016)은 '가고파 국화축제'에 참 가한 관광객의 일탈적 체험이 브랜드 가치 인식에 중요한 역할을 한다고 제시한 바 있다.

또한 You \&Jeon(2016)은 전주한옥마을을 방문한 관 광객의 일탈적 체험이 장소애착을 형성함에 따라 재방문 의도를 높이는 강력한 요인임을 강조했다. 이 외에도 관 광산업 분야의 많은 연구들은 미적 체험이 향후 재방문의 도에 중요한 영향을 미친다는 사실을 꾸준히 입증해왔는 데, Lee \& Yu(2015)는 '대한민국 와인축제'를 방문한 관 광객의 미적 체험이 고객 만족에 중요한 영향을 미친다는 것을 입증하였고 Lee \& Pham \& Seo(2016) 역시 한국 을 방문한 베트남 관광객의 미적 체험이 그들의 재방문의 도를 높이는데 있어 중요한 역할을 수행한다고 밝혔다.

이외에도 Song \& Lee(2015)는 체험경제이론의 오락 적, 교육적, 일탈적, 미적 체험요소들이 템플스테이 방문 객의 감정반응을 자극함으로써 만족과 행동의도를 높일 수 있는 중요 요인임을 주장했다.
이러한 선행연구 결과를 토대로 본 연구에서는 다음과 같은 연구 가설을 설정하였다.

$\mathrm{H} 3$ : 체험경제이론에 따른 생활무용참여자의 체험요 인은 지속적 참여의도에 유의한 영향을 미칠 것 이다.

H3-1: 체험경제이론의 오락적 체험은 지속적 참여의 도에 영향을 미칠 것이다.

H3-2: 체험경제이론의 교육적 체험은 지속적 참여의 도에 영향을 미칠 것이다.

H3-3: 체험경제이론의 일탈적 체험은 지속적 참여의 도에 영향을 미칠 것이다.

H3-4: 체험경제이론의 미적 체험은 지속적 참여의도 에 영향을 미칠 것이다.

\section{이론적 관계모형}

본 연구의 목적을 달성하기 위하여 선행연구 및 가설 을 토대로 설정한 변수간의 인과관계 모형은 다음의 〈Fig $1>$ 과 같다.

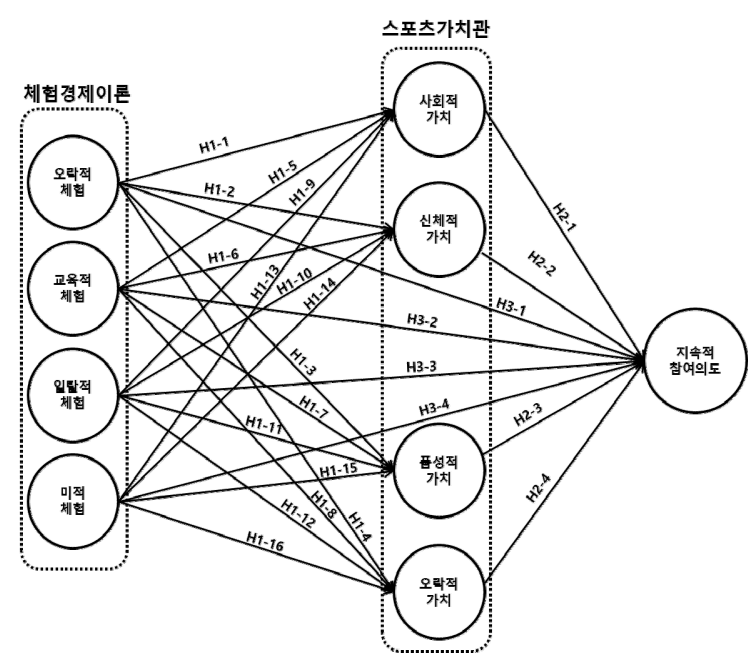

Fig 1. Research mode 


\section{연구방법}

\section{연구대상}

본 연구의 대상은 2017년 12월 기준, '국민생활체육 참여 실태 조사'에 의거하여 생활무용 동호회 가입 인구 밀도가 높은 서울과 경기지역 소재의 사설 스포츠센터 및 문화센터 5 곳, 창의적 체험활동 교육과정 내 무용교과 수 업을 실시하고 있는 3 개교 중등학교, 생활무용 관련 동호 회 5 곳에 직접 참여하고 있는 생활무용참여자를 모집단 으로 선정하였다.

조사대상의 표본은 비확률 표본추출방법(nonprobability sampling) 중 편의표본추출(convenience sampling method)을 사용하여 설문조사를 실시하였으며 조사는 연구자가 설문에 앞서 대상자들에게 설문조사의 목적과 방법 등을 충분히 설명한 후, 응답자가 설문항목에 대해 직접 기재하는 자기평가기입법으로 작성하게 하였다.

조사기간은 2017년 10월 2018년 2월까지 약 5개월 간 실시하였으며, 총 500 부의 설문지를 배포하여 설문응 답 거부자와 이중기입 및 무 기입, 일괄 응답 된 25 부를 제외한 총 475 부의 설문지가 실제 분석에 사용되었다. 연구대상자의 일반적 특성을 살펴보면 아래의 〈Table 1〉 과 같다.

\section{조사도구}

생활무용참여자의 체험요인을 측정하기 위한 문항은 Pine \& Gilmore(1998)가 제시한 4가지 체험영역의 이 론을 근거로 Oh, Fior \& Jeoung(2007)에 의해 개발되 고 Song et al.,(2011)가 국내에서 번안하여 사용한 척 도를 바탕으로 본 연구의 목적과 대상에 부합하도록 수정 ·보완하여 구성하였다. 세부적인 측정항목은 오락적 체험 6 문항, 교육적 체험 6 문항, 일탈적 체험 4 문항, 미적 체 험 4문항으로 구성하였다.

스포츠가치관은 Allport et al.,(1960), Evarett(1962) 에 의해 개발되고 국내 Lee et al.,(2013)의 연구에서 재 사용된 문항을 본 연구의 목적과 대상에 부합하도록 수정 ·보완하여 구성하였다. 세부적인 측정항목은 사회적 가치 3 문항, 신체적 가치 5 문항, 품성적 가치 3 문항, 오락적
Table 1. Demographic characteristic of participants

\begin{tabular}{|c|c|c|c|}
\hline Variables & Classification & $\begin{array}{l}\text { Frequency } \\
\text { (N) }\end{array}$ & $\begin{array}{c}\text { Percentage } \\
(\%)\end{array}$ \\
\hline \multirow{2}{*}{ Gender } & Male & 104 & 21.9 \\
\hline & Female & 371 & 78.1 \\
\hline \multirow{2}{*}{ Area } & Seoul & 248 & 52.2 \\
\hline & Gyeonggi-do & 227 & 47.8 \\
\hline \multirow{4}{*}{ Age } & 10 's & 190 & 40.0 \\
\hline & 20 's & 98 & 20.6 \\
\hline & 30 's & 70 & 14.8 \\
\hline & Over 40's & 117 & 24.6 \\
\hline \multirow[t]{3}{*}{$\begin{array}{l}\text { Participation } \\
\text { field }\end{array}$} & $\begin{array}{c}\text { Dance } \\
\text { (Korean dance, } \\
\text { Ballet, } \\
\text { Modern dance) }\end{array}$ & 194 & 40.8 \\
\hline & Line dance & 141 & 29.7 \\
\hline & broadcasting dance & 140 & 29.5 \\
\hline \multirow{5}{*}{$\begin{array}{c}\text { Participation } \\
\text { experience }\end{array}$} & Less than a year 1 & 139 & 29.3 \\
\hline & $1 \mathrm{yr}$ - less than $2 \mathrm{yrs}$ & 158 & 33.2 \\
\hline & $2 \mathrm{yrs}-$ less than $3 y r s$ & 53 & 11.2 \\
\hline & Over 3yrs & 125 & 26.3 \\
\hline & Total & 475 & 100 \\
\hline
\end{tabular}

가치 3 문항으로 구성하였다.

마지막으로 지속적 참여의도를 측정하기 위한 문항은 국내 Jung(1997)의 연구에서 개발되고 Yoo(2011), Sung(2016)에 의해 재사용된 척도를 바탕으로 본 연 구의 목적과 대상에 부합하도록 수정·보완하여 구성하 였다. 세부적인 측정항목은 총 4 문항으로 구성하였다.

이러한 과정을 통해 본 연구에서 최종적으로 사용된 설문 문항은 체험요인 20 문항, 스포츠가치관 14 문항, 지 속적 참여의도 4 문항 및 일반적 특성 5 문항을 포함한 총 43문항으로 구성하였다. 연구대상의 일반적 특성을 제외 한 모든 문항은 7점 Likert 척도(1점: 전혀 그렇지 않다. 7점: 매우 그렇다)를 이용하여 측정 하였다.

\section{측정도구의 타당도와 신뢰도}

본 연구에 사용된 측정도구(설문 문항)의 집중타당성 을 확보하기 위하여 스포츠경영학 전공 교수, 경영학 박 사, 생활무용 관련 전문가로 구성된 총 3 인의 전문가 집 단을 대상으로 내용 타당도를 검증하였으며, 생활무용참 여자 100명을 대상으로 예비조사(Pilot Test)를 실시하 
Table 2. Confirmatory factor analysis

\begin{tabular}{|c|c|c|c|c|c|c|}
\hline Variables & Factor & $\mathrm{SC}$ & SE & $\mathrm{t}$ & CR AVE & $\begin{array}{c}\text { Cronbach's } \\
\alpha\end{array}$ \\
\hline \multirow{6}{*}{$\begin{array}{l}\text { Entertainment } \\
\text { Experience }\end{array}$} & It is pleasant to see others participating in Dance for all. & .814 & - & - & \multirow{6}{*}{$-.991 .951$} & \multirow{6}{*}{.934} \\
\hline & When Dance for all, people's eyes and interests are attractive. & .910 & .042 & 24.76 & & \\
\hline & It is fun to see others participating in Dance for all. & .899 & .041 & 24.30 & & \\
\hline & It is enjoy to see others participating in Dance for all. & .879 & .044 & 23.45 & & \\
\hline & It is exciting to see others participating in Dance for all. & .777 & .047 & 19.52 & & \\
\hline & It is interesting to see others participating in Dance for all. & .759 & .046 & 18.90 & & \\
\hline \multirow{6}{*}{$\begin{array}{l}\text { Education } \\
\text { Experience }\end{array}$} & Participation in Dance for all improves my knowledge. & .834 & - & - & \multirow{6}{*}{.951} & \multirow{6}{*}{.942} \\
\hline & $\begin{array}{l}\text { Participation in Dance for all has improved the technical aspects of the } \\
\text { movement. }\end{array}$ & .841 & .046 & 22.76 & & \\
\hline & Participation in Dance for all stimulated my educational curiosity. & .861 & .042 & 23.66 & & \\
\hline & Participation in Dance for all is a learning experience. & .851 & .048 & 23.24 & & \\
\hline & Participation in Dance for all is an educational experience. & .885 & .042 & 24.80 & & \\
\hline & Participation in Dance for all has improved the artistic aspect of the movement. & .858 & .047 & 23.55 & & \\
\hline \multirow{4}{*}{$\begin{array}{l}\text { Deviant } \\
\text { Experience }\end{array}$} & When I participated in Dance for all, I felt like I was a different me. & .858 & - & - & \multirow{4}{*}{.964} & \multirow{4}{*}{.945} \\
\hline & When I participated in Dance for all, I felt like I was in different place or time. & .920 & .036 & 27.66 & & \\
\hline & Participation in Dance for all makes me feel different. & .889 & .036 & 26.07 & & \\
\hline & When I participate in Dance for all, I felt out of the ordinary. & .753 & .038 & 19.70 & & \\
\hline \multirow{4}{*}{$\begin{array}{l}\text { Aesthetic } \\
\text { Experience }\end{array}$} & $\begin{array}{l}\text { When I participate in Dance for all, my body feels like it is moving in balance } \\
\text { and harmony. }\end{array}$ & .826 & - & - & \multirow{4}{*}{.943} & \multirow{4}{*}{.920} \\
\hline & The movement of the body through the Dance for all is interesting. & .901 & .049 & 23.76 & & \\
\hline & I am interested in changing the space of motion when performing Dance for all. & .757 & .049 & 18.64 & & \\
\hline & Participation in Dance for all gives me physical pleasure. & .728 & .058 & 17.65 & & \\
\hline \multirow{3}{*}{ Social Value } & Participation in Dance for all is helpful for interpersonal relationships. & .827 & - & - & \multirow[b]{2}{*}{.967} & \multirow{3}{*}{.927} \\
\hline & Participation in Dance for all helps make new friends. & .928 & .041 & 26.51 & .989 & \\
\hline & Participation in Dance for all helps to improve cooperation. & .956 & .042 & 27.58 & & \\
\hline \multirow{5}{*}{ Physical Value } & Participation in Dance for all helps control your weight. & .867 & - & - & \multirow{5}{*}{.951} & \multirow{5}{*}{.918} \\
\hline & Participation in Dance for all helps to improve physical strength. & .867 & .042 & 25.44 & & \\
\hline & Participation in Dance for all helps to develop a balanced physique. & .921 & .039 & 28.57 & & \\
\hline & Participation in Dance for all helps to improve health. & .798 & .050 & 21.96 & & \\
\hline & Participation in Dance for all helps prevent adult diseases. & .757 & .051 & 15.78 & & \\
\hline \multirow{3}{*}{$\begin{array}{l}\text { Personality } \\
\text { Value }\end{array}$} & Participation in Dance for all helps to increase patience. & .841 & - & - & \multirow{3}{*}{.948} & \\
\hline & Participation in Dance for all helps to promote cheerfulness. & .892 & .057 & 19.02 & & .871 \\
\hline & Participation in Dance for all helps to improve composure. & .714 & .054 & 20.26 & & \\
\hline & I often watch performances or broadcasts related to Dance for all. & .876 & - & - & & \\
\hline Entertainment & I usually take part in the Dance for all in my spare time. & .837 & .051 & 20.95 & $\begin{array}{ll}979 & .939\end{array}$ & .814 \\
\hline & $\begin{array}{l}\text { There are many entertainment factors(pleasure) obtained through participation } \\
\text { in Dance for all. }\end{array}$ & .669 & .073 & 15.76 & & \\
\hline & I will continue to participate in the Dance for all. & .845 & - & - & & \\
\hline Continuous & Participation in the Dance for all is very important to me. & .940 & .040 & 28.70 & & \\
\hline $\begin{array}{l}\text { Participation } \\
\text { Intention }\end{array}$ & I will try to participate in the Dance for all. & .907 & .039 & 26.21 & 1.964 & .938 \\
\hline & I want to do the Dance for all whenever I have time. & .875 & .039 & 24.54 & & \\
\hline
\end{tabular}


여 설문 문항을 최종 수정·보완하여 신뢰도를 확보하였 다. 본 연구에 사용된 측정도구(설문 문항)의 집중타당성 과 판별타당성을 검증하기 위해 확인적 요인분석을 실시 한 결과는 다음의 〈Table 2 〉와 같다.

Bagozzi \& Dholakia(2002)에 따르면 CFI, NFI, TLI은 .8 .9 이상일 때, RMR과 RMSEA는 .05 또는 .08 이하일 때 가장 좋은 모델이라는 평가하였다. 이에 확인적 요인분석 결과 본 연구의 모형 적합도는 $\mathrm{X}^{2}=382.748, \mathrm{df}=51, \mathrm{CFI}$ 는 .985, NFI는 .978, TLI는 .970, RMR은 .026, RMSEA는 .068로 나타나 Bagozzi $\&$ Dholakia(2002)가 제시한 수용 수준을 충족시키고 있어 비교적 우수한 모형인 것으로 나타났다.

또한 각 변인별 집중타당성 (convergent validity)을 분석하기 위하여 개념 신뢰도(construct reliability)와 평균분산 추출지수(average variance extracted: AVE) 값을 산출한 결과 모든 변인의 개념 신뢰도는 .979 .992, AVE는 .939 .967으로 나타나 Kim(2010) 가 제시한 적합기준치(요인적재치>.5, C.R.>.7, AVE〉.5) 의 값을 충족시켜 각 변인들은 집중 타당성을 갖는 것으 로 나타났다. $\operatorname{Kim}(2010)$ 는 신뢰도 검증을 실시하였을 경우, 문항 전체 수준인 경우 알파계수가 .5이상이면 신 뢰도에는 문제가 없다고 설명하고 있다. 따라서 본 연구 에서는 측정도구(설문 문항)의 신뢰도를 검증하기 위하 여 Cronbach's $\alpha$ 값을 이용한 내적 일관성(internal consistency reliability) 분석방법을 사용하였으며, 분
석결과 Cronbach's $\alpha$ 값이 .814 .945으로 비교적 높은 신뢰도를 갖는 것으로 나타났다.

\section{자료처리방법}

본 연구의 자료처리를 위하여 최종 분석에 활용된 설 문은 부호화과정(Cording)과 오류 검토 작업을 거쳐 SPSS 21.0 및 AMOS 18.0 프로그램을 이용하여 자료분 석을 실시한 구체적인 내용은 다음과 같다.

첫째, 연구대상의 일반적 특성을 알아보기 위하여 빈 도분석을 실시하였다. 둘째, 각 변수의 타당도 검증을 위 하여 확인적 요인분석을 실시하였으며, 문항 간 내적 일 관성을 위하여 Cronbach' $\alpha$ 계수를 산출하여 신뢰도를 검증하였다. 셋째, 변인들 간의 관계를 분석하기 위하여 상관관계분석을 실시하였으며, 구조적 모형을 도출하기 위하여 구조방정식을 (structure equation modeling: $\mathrm{SEM})$ 을 실시하였다.

\section{연구결과}

\section{상관관계 분석}

각 변인간의 상관관계를 확인하기 위해 생활무용참여 자의 체험요인, 스포츠가치관, 지속적 참여의도의 상관 관계 분석을 실시한 결과는 다음의 〈Table 3)과 같다. 분

Table 3. Correlation analysis result

\begin{tabular}{lcccccccc}
\hline \hline \multicolumn{1}{c}{ Variables } & 1 & 2 & 3 & 4 & 5 & 6 & 7 & 8 \\
\hline Entertainment Experience & 1 & & & & & & \\
Education Experience & $.580^{* *}$ & 1 & & & & & & \\
Deviant Experience & $.577^{* *}$ & $.663^{* *}$ & 1 & & & & & \\
Aesthetic Experience & $.631^{* *}$ & $.709^{* *}$ & $.679^{* *}$ & 1 & & & & \\
Social Value & $.530^{* *}$ & $.549^{* *}$ & $.545^{* *}$ & $.575^{* *}$ & 1 & & & \\
Physical Value & $.506^{* *}$ & $.511^{* *}$ & $.430^{* *}$ & $.560^{* *}$ & $.710^{* *}$ & 1 & & \\
Characteristic Value & $.630^{* *}$ & $.572^{* *}$ & $.559^{* *}$ & $.599^{* *}$ & $.606^{* *}$ & $.712^{* *}$ & 1 & \\
Entertainment Value & $.607^{* *}$ & $.516^{* *}$ & $.598^{* *}$ & $.611^{* *}$ & $.553^{* *}$ & $.512^{* *}$ & $.655^{* *}$ & 1 \\
Continuous Participation Intention & $.516^{* *}$ & $.589^{* *}$ & $.538^{* *}$ & $.662^{* *}$ & $.632^{* *}$ & $.573^{* *}$ & $.566^{* *}$ & $.660^{* *}$ \\
\hline \hline
\end{tabular}

** $p<.01$ 
석결과, 상관계수의 값이 .430 .712까지의 범위에 있어 .8 이상의 높은 상관관계를 보여주는 변수가 없으므로 다 중공선성에는 문제가 없는 것으로 나타났다. 또한 Fornel \& Larcker(1981)은 상관계수의 제곱 값보다 $\mathrm{AVE}$ 값이 크면 판별타당성을 확보할 수 있다고 제시하 였다(이정학, 김형근, 김재환, 2017).

이를 근거로 본 연구의 가장 큰 상관계수 제곱 값과 아 래의 〈Table 3〉에 제시된 가장 작은 AVE 값을 비교해 볼 때, 상관계수의 가장 큰 제곱 값은 $.507(=.712), \mathrm{AVE}$ 의 가장 작은 값은 .939로 나타나 판별타당성이 확보되었음 을 확인할 수 있다.

\section{연구모형 검증}

구조모형의 모수 추정은 최대우도법을 이용 하였으 며, 연구모형의 적합도를 검증한 결과는 〈Table 4〉 와 같다.

Table 4. Fit index of research model

\begin{tabular}{ccccccccc}
\hline \hline A construct & $\mathrm{X}^{2}$ & df & $\mathrm{p}$ & CFI & NFI & TLI & RMR & RMSEA \\
\hline Acceptance level 3652.016 & 641 & .000 & .935 & .905 & .925 & .057 & .064 \\
\hline \hline
\end{tabular}

분석 결과, $\mathrm{X}^{2}$ 값은 $3652.016(\mathrm{df}=641, \mathrm{p}=.000)$ 으로 나타났으며 $\mathrm{CFI}=.935, \mathrm{NFI}=.905, \mathrm{TLI}=.92$ $5, \mathrm{RMR}=.057, \mathrm{RMSEA}=.064$ 로 나타났다. 일반적 으로 모델의 전반적인 적합도를 평가하는 $\mathrm{CFI}, \mathrm{NFI}$, TLI의 지표는 .8 .9 이상일 때, RMR, RMSEA는 .8 이하이면 좋은 모델로 평가된다(Kim, 2010).

따라서 본 연구모형은 채택하기에 적합한 모형으로 판명되었으며, 본 연구에서 설정한 연구가설과 모형은 실증자료를 비교적 잘 설명하고 있다.

\section{생활무용참여자의 체험요인, 스포츠가치관, 지속적 참여의도간의 인과관계 검증}

참여의도간의 관계를 규명하기 위해 구조방정식 모형 을 분석한 결과는 〈Table 5〉와 같다.
첫째, 생활무용참여자의 체험요인과 스포츠가치관에 대한 실증적 분석 결과 가설 $1-1(\beta=.212, \mathrm{t}=4.993)$ 의 경로계수 값은 통계적으로 유의하게 나타나 “체험경제이 론의 오락적 체험은 스포츠가치관 중 사회적 가치에 영향 을 미칠 것이다'의 가설이 채택되었다. 가설 $1-2(\beta$ $=.177, \mathrm{t}=4.412)$ 의 경로계수 값은 통계적으로 유의하 게 나타나 "체험경제이론의 오락적 체험은 스포츠가치관 중 신체적 가치에 영향을 미칠 것이다'의 가설이 채택되 었다. 가설 $1-3(\beta=.346, \mathrm{t}=7.374)$ 의 경로계수 값은 통 계적으로 유의하게 나타나 “체험경제이론의 오락적 체험 은 스포츠가치관 중 품성적 가치에 영향을 미칠 것이다' 의 가설이 채택되었다. 가설 $1-4(\beta=.326, \mathrm{t}=7.068)$ 의 경로계수 값은 통계적으로 유의하게 나타나 “체험경제이 론의 오락적 체험은 스포츠가치관 중 오락적 가치에 영향 을 미칠 것이다'의 가설이 채택되었다. 가설 $1-5(\beta$ $=.109, \mathrm{t}=2.60)$ 의 경로계수 값은 통계적으로 유의한 것 으로 나타나 “체험경제이론의 교육적 체험은 스포츠가치 관 중 사회적 가치에 영향을 미칠 것이다'의 가설이 채택 되었다. 가설 1-6( $\beta=.078, \mathrm{t}=1.97)$ 의 경로계수 값은 통 계적으로 유의한 것으로 나타나 “체험경제이론의 교육적 체험은 스포츠가치관 중 신체적 가치에 영향을 미칠 것이 다'의 가설이 채택되었다. 가설 $1-7(\beta=.104, \mathrm{t}=2.43)$ 의 경로계수 값은 통계적으로 유의한 것으로 나타나 “체험경 제이론의 교육적 체험은 스포츠가치관 중 품성적 가치에 영향을 미칠 것이다'의 가설이 채택되었다. 가설 $1-8(\beta$ $=.001, \mathrm{t}=.014)$ 의 경로계수 값은 통계적으로 유의하지 않은 것으로 나타나 “체험경제이론의 교육적 체험은 스포 츠가치관 중 오락적 가치에 영향을 미칠 것이다'의 가설 이 기각되었다. 가설 $1-9(\beta=.180, \mathrm{t}=4.262)$ 의 경로계 수 값은 통계적으로 유의한 것으로 나타나 '체험경제이론 의 일탈적 체험은 스포츠가치관 중 사회적 가치에 영향을 미칠 것이다'의 가설이 채택되었다. 가설 $1-10(\beta=076$, $\mathrm{t}=1.929$ )의 경로계수 값은 통계적으로 유의하지 않은 것으로 나타나

“체험경제이론의 일탈적 체험은 스포츠가치관 중 신체 적 가치에 영향을 미칠 것이다'의 가설이 기각되었다. 가 설 $1-11(\beta=.203, \mathrm{t}=4.632)$ 의 경로계수 값은 통계적으 로 유의한 것으로 나타나 “체험경제이론의 일탈적 체험은 스포츠가치관 중 품성적 가치에 영향을 미칠 것이다'의 
Table 5. Hypothesis testing result

\begin{tabular}{|c|c|c|c|c|c|c|}
\hline & $\mathrm{H}$ & Path & SE & $\mathrm{CR}$ & $\mathrm{P}$ & $\begin{array}{l}\text { Accept } \\
\text { /Reject }\end{array}$ \\
\hline H1-1 & Entertainment Experience $\rightarrow$ Social Value & .212 & .035 & 4.993 & $.000 * * *$ & Accept \\
\hline $\mathrm{H} 1-2$ & Entertainment Experience $\rightarrow$ Physical Value & .177 & .028 & 4.412 & $.000 * * *$ & Accept \\
\hline H1-3 & Entertainment Experience $\rightarrow$ Characteristic Value & .346 & .033 & 7.374 & $.000 * * *$ & Accept \\
\hline H1-4 & Entertainment Experience $\rightarrow$ Entertainment Value & .326 & .036 & 7.068 & $.000^{* * *}$ & Accept \\
\hline H1-5 & Education Experience $\rightarrow$ Social Value & .109 & .038 & 2.606 & $.009 * *$ & Accept \\
\hline H1-6 & Education Experience $\rightarrow$ Physical Value & .078 & .031 & 1.970 & $.049^{*}$ & Accept \\
\hline H1-7 & Education Experience $\rightarrow$ Characteristic Value & .104 & .033 & 2.434 & $.015^{*}$ & Accept \\
\hline H1-8 & Education Experience $\rightarrow$ Entertainment Value & .001 & .038 & .014 & .988 & Reject \\
\hline H1-9 & Deviant Experience $\rightarrow$ Social Value & .180 & .027 & 4.262 & $.000 * * *$ & Accept \\
\hline H1-10 & Deviant Experience $\rightarrow$ Physical Value & .076 & .022 & 1.929 & .054 & Reject \\
\hline H1-11 & Deviant Experience $\rightarrow$ Characteristic Value & .203 & .024 & 4.632 & $.000 * * *$ & Accept \\
\hline H1-12 & Deviant Experience $\rightarrow$ Entertainment Value & .322 & .028 & 7.018 & $.000 * * *$ & Accept \\
\hline H1-13 & Aesthetic Experience $\rightarrow$ Social Value & .477 & .043 & 10.547 & $.000 * * *$ & Accept \\
\hline H1-14 & Aesthetic Experience $\rightarrow$ Physical Value & .621 & .039 & 13.036 & $.000^{* * *}$ & Accept \\
\hline H1-15 & Aesthetic Experience $\rightarrow$ Characteristic Value & .489 & .043 & 9.469 & $.000^{* * *}$ & Accept \\
\hline H1-16 & Aesthetic Experience $\rightarrow$ Entertainment Value & .458 & .045 & 9.370 & $.000^{* * *}$ & Accept \\
\hline $\mathrm{H} 2-1$ & Social Value $\rightarrow$ Continuous Participation Intention & .176 & .045 & 3.935 & $.000 * * *$ & Accept \\
\hline $\mathrm{H} 2-2$ & Physical Value $\rightarrow$ Continuous Participation Intention & .088 & .060 & 1.759 & .079 & Reject \\
\hline $\mathrm{H} 2-3$ & Characteristic Value $\rightarrow$ Continuous Participation Intention & .095 & .062 & 1.822 & .068 & Reject \\
\hline $\mathrm{H} 2-4$ & Entertainment Value $\rightarrow$ Continuous Participation Intention & .487 & .064 & 8.088 & $.000 * * *$ & Accept \\
\hline H3-1 & Entertainment Experience $\rightarrow$ Continuous Participation Intention & .081 & .040 & 1.702 & .089 & Reject \\
\hline $\mathrm{H} 3-2$ & Education Experience $\rightarrow$ Continuous Participation Intention & .164 & .035 & 4.406 & $.000 * * *$ & Accept \\
\hline $\mathrm{H} 3-3$ & Deviant Experience $\rightarrow$ Continuous Participation Intention & .045 & .029 & 1.037 & .300 & Reject \\
\hline $\mathrm{H} 3-4$ & Aesthetic Experience $\rightarrow$ Continuous Participation Intention & .281 & .070 & 3.918 & $.000^{* * *}$ & Accept \\
\hline
\end{tabular}

${ }^{*} p<.05,{ }^{* *} p<.01,{ }^{* * *} p<.001$

가설이 채택되었다. 가설 $1-12(\beta=.322, \mathrm{t}=7.018)$ 의 경 로계수 값은 통계적으로 유의한 것으로 나타나 '체험경제 이론의 일탈적 체험은 스포츠가치관 중 오락적 가치에 영 향을 미칠 것이다'의 가설이 채택되었다. 가설 $1-13(\beta$ $=.477, \mathrm{t}=10.547$ )의 경로계수 값은 통계적으로 유의한 것으로 나타나 '체험경제이론의 미적 체험은 스포츠가치 관 중 사회적 가치에 영향을 미칠 것이다'의 가설이 채택되 었다. 가설 1-14(.621, $\mathrm{t}=13.036)$ 의 경로계수 값은 통계 적으로 유의한 것으로 나타나 “체험경제이론의 미적 체험 은 스포츠가치관 중 신체적 가치에 영향을 미칠 것이다'의 가설이 채택되었다. 가설 $1-15(\beta=.489, \mathrm{t}=9.469)$ 의 경
로계수 값은 통계적으로 유의한 것으로 나타나 “체험경제 이론의 미적 체험은 스포츠가치관 중 품성적 가치에 영향 을 미칠 것이다'의 가설이 채택되었다. 가설 1-16( $\beta$ $=.458, \mathrm{t}=9.370)$ 의 경로계수 값은 통계적으로 유의한 것으로 나타나 '체험경제이론의 미적 체험은 스포츠가치 관 중 오락적 가치에 영향을 미칠 것이다'의 가설이 채택 되었다.

둘째, 생활무용참여자의 스포츠가치관과 지속적 참여 의도에 대한 실증적 분석 결과 가설 $2-1(\beta=.176$, $\mathrm{t}=3.935)$ 의 경로계수 값은 통계적으로 유의한 것으로 나타나 '스포츠가치관 중 사회적 가치는 지속적 참여의도 
에 영향을 미칠 것이다'의 가설이 채택되었다. 가설 2-2 $(\beta=.088, t=1.759)$ 의 경로계수 값은 통계적으로 유의하 지 않은 것으로 나타나 '스포츠가치관 중 신체적 가치는 지 속적 참여의도에 영향을 미칠 것이다'의 가설이 기각되었 다. 가설 2-3 $\beta=.095, \mathrm{t}=1.822)$ 의 경로계수 값은 통계 적으로 유의하지 않은 것으로 나타나 '스포츠가치관 중 품 성적 가치는 지속적 참여의도에 영향을 미칠 것이다'의 가 설이 기각되었다. 가설 $2-4(\beta=.487, \mathrm{t}=8.088)$ 의 경로계 수 값은 통계적으로 유의한 것으로 나타나 '스포츠가치관 중 오락적 가치는 지속적 참여의도에 영향을 미칠 것이 다'의 가설이 채택되었다.

셋째, 생활무용참여자의 체험요인과 지속적 참여의도 에 대한 실증적 분석 결과 가설 3- $1(\beta=.081, \mathrm{t}=1.702)$ 의 경로계수 값은 통계적으로 유의하지 않은 것으로 나타 나 “체험경제이론 중 오락적 체험은 지속적 참여의도에 영향을 미칠 것이다'의 가설이 기각되었다. 가설 3-2( $\beta$ $=.164, \mathrm{t}=4.406)$ 의 경로계수 값은 통계적으로 유의한 것으로 나타나 '체험경제이론 중 교육적 체험은 지속적 참여의도에 영향을 미칠 것이다'의 가설이 채택되었다. 가설 3-3( $\beta=.045, \mathrm{t}=1.037)$ 의 경로계수 값은 통계적으 로 유의하지 않은 것으로 나타나 '체험경제이론 중 일탈 적 체험은 지속적 참여의도에 영향을 미칠 것이다'의 가 설이 기각되었다. 가설 $3-4(\beta=.281, \mathrm{t}=3.918)$ 의 경로 계수 값은 통계적으로 유의한 것으로 나타나 '체험경제이 론 중 미적 체험은 지속적 참여의도에 영향을 미칠 것이 다'의 가설이 채택되었다.

\section{논 의}

본 연구는 체험경제이론에 따른 생활무용참여자의 스 포츠가치관 및 지속적 참여의도의 구조적 관계를 분석하 였다. 분석된 연구결과를 바탕으로 다음과 같은 논의를 제시하였다.

체험경제이론의 체험요인과 스포츠가치관, 지속적 참여 의도의 구조모형을 분석한 결과 첫째, 체험경제이론의 체 험요인 중 오락적 체험은 스포츠가치관의 모든 요인에 유 의한 영향을 미치는 것으로 나타나 오락적 체험과 스포츠 가치관의 가설은 모두 채택되었다. Park \& $\operatorname{Han}(2016)$ 은
무용 수업 참여의 즐거움이 새로운 친구를 사귀고 여러 사람들과의 친분을 형성하는 사회적 가치를 인식하게 한 다고 하였으며, 체험 마케팅의 성공 사례로 손꼽히는 미 국의 아메리칸 걸(American girl)은 표적 고객에게 가족 애, 사랑, 우정, 용서, 화해 등과 같은 사회적 가치와 품성 적 가치를 인형 캐릭터와의 체험을 통해 자연스럽게 습득 시키는 마케팅 전략을 내세우고 있다(Park \& Pack \& Cha, 2007). 또한 Choi \& Kim \& kim(2000)는 인간의 인지와 지각을 고려한 게임 디자인 요소 분석을 통해 이 용자가 경험하게 되는 가장 중요한 요소는 흥미와 호기심 이 합성된 즐거움이라고 강조하며 본 연구의 결과를 이론 적으로 지지하고 있다.

생활무용 참여자의 대부분은 기본적으로 생활무용에 대한 관여도가 높은 상태로 생활무용에 참여 하지만 이를 근거로 오로지 전문성만을 강조한 프로그램이 운영된다 면 이전의 순수무용과 대중 사이의 진입장벽이라는 악순 환이 생길 위험성이 크다. 따라서 일반인이 쉽게 받아들 일 수 있는 움직임 수준에서의 난이도 조절과 더불어 오 락성이 적절히 가미된 참신한 생활무용프로그램을 구성 하여 참가자들의 오락적 체험의 경험을 높여야 할 것이다.

둘째, 체험경제이론의 교육적 체험은 오락적 가치를 제외한 모든 요인에 유의한 영향을 미치는 것으로 나타났 다. 따라서 오락적 가치를 제외한 스포츠가치관의 모든 가설은 채택되었다. $\operatorname{Kim}(2012)$ 은 대학생의 동계레저스 포츠 참여에 있어 관련 지식 및 기술 습득과 같은 교육적 체험이 높을수록 사회적 가치, 신체적 가치, 품성적 가치 가 높게 나타난다고 보고함에 따라 본 연구의 결과를 이 론적으로 뒷받침하고 있다. 반면, 교육적 체험이 오락적 가치에 유의한 영향을 미칠 것이라는 가설이 기각된 것은 생활무용의 참여가 단순한 재미를 위해 즐기는 오락적 수 준을 뛰어넘어 생활무용의 체험을 통해 진지하게 무용 동 작을 배우고, 익히는 학습의 장임을 입증한 결과라고 볼 수 있다.

때문에 평생교육의 일환으로써 생활무용의 지속적인 참여를 유도하기 위해서는 흥미나 재미 요소들로만 구성 된 단순한 형태의 프로그램 운영이 아닌 자기개발이나 자 기관리 등에 도움이 될 수 있는 체험적 요소들을 파악하 는 작업이 필요하다. 예를 들어 생활무용프로그램의 반 편성을 초급반·중급반·고급반·오디션반·자격증반 등으로 
구성하여 운영한다면 참여자들로 하여금 신체의 움직임 수준 향상 및 목적 달성을 위한 동기를 충분히 자극시킬 수 있을 것이라 사료된다.

셋째, 체험경제이론 중 일탈적 체험은 신체적 가치에 유의한 영향을 미치지 않는 것으로 나타나 이에 대한 가 설은 기각되었다. 이는 생활무용참여자들의 일탈적 체험 이 몰입과 극복이라는 감성적 인식을 제공하여 자기표출 로 해소되는 최상의 쾌감을 경험하게 되지만 이러한 경험 은 체력을 유지·증진하거나 체중을 조절하는 등의 신체적 가치에는 도움이 되지 않는 다는 것을 의미한다. 반면, 생 활무용참여를 통해 경험하는 일탈적 체험이 사회적 가치, 품성적 가치, 오락적 가치에는 유의한 영향을 미치는 것 으로 나타났다.

이러한 결과를 토대로 생활무용참여자들이 생활무용 을 통해 잠시나마 일상생활과 분리되는 일탈적 체험을 경 험할 수 있도록 실내 인테리어, 조명, 음악 등과 같은 시 설적 요소 등을 활용하여 작품 안무에 맞는 분위기 연출 로 생활무용에 몰입할 수 있는 환경을 조성한다면, 참여 자들로 하여금 보다 높은 일탈적 체험의 경험을 제공할 수 있을 것이다.

넷째, 체험경제이론 중 미적 체험은 스포츠가치관의 모든 요인에 유의한 영향을 미치는 것으로 나타나 미적 체험과 스포츠가치관의 가설은 모두 채택되었다. $\operatorname{Park}(2001)$ 은 미학적 체험을 통해 다양한 종류의 가치 들이 인식된다고 하였으며, Wakefield \& Baker(1998) 는 매장의 조명, 음향, 온도, 실내 장식, 실내 구조 등이 재미와 같은 가치 인식과 매장 선호에 영향을 미친다고 제시한 바 있다. 또한 $\mathrm{Oh}(2000)$ 은 스포츠 참여 경험이 스포츠의 경제적, 심미적, 신체적 가치에 유의한 영향을 미친다고 언급하였으며, Hyeon(2006), Lee(2011), Oh et al., (2011)은 우수하거나 편리한 시설을 이용할 때, 고객들은 미적 체험을 경험하게 되고 이를 통해 신뢰와 만족감을 높일 수 있다고 하여 본 연구와 그 결과가 일치 한다. 이는 미적 체험 요인이 생활무용참여자의 스포츠가 치관 형성에 있어 매우 중요한 요인으로 작용함을 의미한다.

따라서 생활무용참여자의 미적 체험을 극대화시키기 위해서는 안무 작품에 어울리는 의상이나 소품을 적절하 게 활용하여 참여자로 하여금 시각적인 요소를 자극시킬 필요가 있다. 또한 생활무용지도자 역시 청결한 몸 상태
와 단정한 용모 유지 등과 같은 외적 측면에서의 관리가 반드시 필요하다.

다섯째, 스포츠가치관의 사회적 가치와 오락적 가치는 지속적 참여의도에 유의한 영향을 미치는 것으로 나타나 가설이 채택되었다. 이와 관련하여 Jung et al.,(2012) 은 스포츠가치관의 사회적 가치, 품성적 가치, 오락적 가 치가 운동지속수행에 유의한 영향을 미친다고 하였으며 $\operatorname{Kim}(2014)$ 는 신체적, 심리적 효과가 운동지속의사에 영 향을 미친다고 보고한 바 있어 본 연구의 결과를 부분적 으로 지지해주고 있다. 이러한 연구결과는 생활무용을 즐 기고자 하는 오락적 가치와 대인관계를 중요시 여기는 사 회적 가치관이 함께 형성된다면 이는 곧 생활무용의 지속 적 참여로 이어질 수 있는 가능성이 높아진다는 것을 의 미한다. 즉, 생활무용의 참여의 대부분은 생활무용에 대 한 관심과 흥미로 시작되지만 이를 지속시킬 수 있는 중 요 요인은 함께 참여하는 사람들과의 교류와 유대관계라 고 할 수 있다.

따라서 생활무용프로그램 운영에 있어 생활무용참가 자들이 상호작용하며 공감대를 형성하고 이를 통해 소속 감과 결속력을 높일 수 있는 단체 안무 연출, 발표회 등과 같은 이벤트성이 가미된 프로그램이 고려되어야 할 것이다. 여섯째, 체험경제이론의 교육적 체험과 미적 체험은 지속적 참여의도에 유의한 영향을 미치는 것으로 나타나 가설이 채택되었다. 이는 생활무용 참여를 통해 느껴지는 일시적이고 단순한 감정들(즐거움, 쾌락, 해방감, 자유감 등)은 참여의 지속성으로 연결되는데 어려움이 있지만 반대로 생활무용을 통해 학습된 전문지식, 기술습득, 기 술향상 등과 같은 교육적 체험과 미적 체험은 '평생교육' 의 의미로써 지속적인 생활무용의 참여를 이끌어내는 강 력한 변수로 작용함을 나타낸다. 이에 Sung(2016)는 학 교스포츠클럽을 통해 체험한 경험을 즐겁게 느끼고 소중 하게 생각하는 학생들이 다음 수업시간에서 또 다른 기술 을 배우기를 희망한다고 하였으며, Lim \& Lee(2019)는 해양스포츠이벤트의 교육적 체험과 미적 체험이 방문객 의 만족을 높여 차후 행동의도에 긍정적인 역할을 한다고 언급한 바 있다. 이는 본 연구의 결과와 동일하게 생활무 용이 '평생교육'의 의미로써 발전할 수 있는 발전 가능성 과 방향을 시사하고 있다.

즉, 생활무용이 '평생교육'으로써의 가치를 실현하기 
위해서는 참여자들에게 교육적 측면에서의 동기를 적절 하게 부여하고 수행 과정에서의 도전과 성취감 등의 성공 적 경험을 제공하여 지속적인 참여를 유도할 수 있는 생 활무용 프로그램 개발과 실천이 요구된다. 이는 현재 참 여자 전체가 동일한 작품을 익히고 연습하는 생활무용의 일률 보편적 학습 형태로는 불가능하다. 따라서 생활무용 지도자의 전문성을 바탕으로 참여 대상의 특성(성별, 연 령, 신체의 기능수준, 성향 등)을 고려한 다양한 프로그 램을 제공하여 참여자들이 자신에게 맞는 프로그램을 선 택할 수 있도록 해야 한다. 더불어 생활무용지도자의 양 성기관은 얼마나 많은 생활무용지도자들을 배출하느냐 의 관점에서 벗어나 우수한 지도자 양성을 위한 체계적 교육프로그램의 도입과 질적 개선이 요구된다.

또한 Choi(2013)은 농어촌체험 휴양마을의 오락적 체 험, 교육적 체험, 일탈적 체험, 미적 체험이 방문가치와 행동의도에 유의한 영향을 미친다고 보고하였으며, $\operatorname{Park}$ (2002) 역시 실내에서 상업적으로 운영하는 공간의 환경적 차이로 감각과 관계부분의 영향 관계가 나타난다 고 밝혀 본 연구의 결과를 이론적으로 지지하고 있다. 즉, 생활무용이 이루어지는 장소나 공간 등의 환경적 요소는 시각적으로 아름다움이라는 미적 체험을 인식하게 하고 이는 전체성과 조화라는 감성적 인식을 제공하기 때문에 생활무용이 이루어지는 실내공간의 시각적 인테리어 구 조 및 시설의 편리함, 청결함 유지 등은 생활무용의 지속 적 참여를 유도하는 요소가 될 수 있다.

따라서 지방자치단체 및 사설단체는 지역사회의 문화 예술정책의 일환으로 운영하고 있는 주민자치센터 및 여 성회관, 생활정보관 등의 운영 및 관리 형태를 수시로 점 검하고 참여 회원들의 불편사항 및 요구사항을 적극적으 로 수용해야 할 것이다.

\section{결론 및 제언}

\section{결론}

본 연구는 생활무용참여자의 체험요인, 스포츠가치관, 지속적 참여의도의 관계 규명을 통해 생활무용 분야의 활 성화를 위한 프로그램 개발 및 효율적 운영전략 수립의
실증적 기초자료를 제시하는데 그 목적을 두었다. 본 연구 결과와 논의를 바탕으로 다음과 같은 결론을 도출하였다.

첫째, 체험경제이론의 오락적 체험은 스포츠가치관에 유의한 영향을 미칠 것이라는 가설을 검증한 결과 오락적 체험은 스포츠가치관의 모든 요인에 유의한 영향을 미친 다. 둘째, 체험경제이론의 교육적 체험은 스포츠가치관 에 유의한 영향을 미칠 것이라는 가설을 검증한 결과 교 육적 체험은 오락적 가치를 제외한 모든 요인에 유의한 영향을 미친다. 셋째, 체험경제이론의 일탈적 체험은 스 포츠가치관에 유의한 영향을 미칠 것이라는 가설을 검증 한 결과 일탈적 체험은 신체적 가치를 제외한 모든 요인 에 유의한 영향을 미친다. 넷째, 체험경제이론의 미적 체 험은 스포츠가치관에 유의한 영향을 미칠 것이라는 가설 을 검증한 결과 미적 체험은 스포츠가치관의 모든 요인에 유의한 영향을 미친다. 다섯째, 스포츠가치관은 지속적 참여의도에 유의한 영향을 미칠 것이라는 가설을 검증한 결과 스포츠가치관의 사회적 가치와 오락적 가치는 지속 적 참여의도에 유의한 영향을 미친다.

여섯째, 체험경제이론은 지속적 참여의도에 유의한 영 향을 미칠 것이라는 가설을 검증한 결과 체험경제이론의 오락적 체험과 미적 체험은 지속적 참여의도에 유의한 영 향을 미친다.

결론적으로 본 연구는 생활무용참여자의 체험요인, 스 포츠가치관, 지속적 참여의도간의 변수들이 대부분 서로 유의한 영향을 미치고 있음을 검증하였다. 이러한 연구결 과는 기존의 연구에서는 다루어지지 않았던 생활무용 분 야의 부족한 지식체계 형성과 더불어 생활무용 인구의 저 변확대와 생활무용의 활성화 방안에 학술적 기초자료를 제공했다는 점에서 학문적 의의가 있다.

\section{제언}

본 연구를 수행함에 있어 연구의 한계점과 후속 연구 를 위한 제언은 다음과 같다.

첫째, 본 연구는 서울·경기 지역에 소재한 생활무용참 여자를 모집단으로 한정하였기에 연구에서 제시된 결과 를 일반화 시키는데 표본의 대표성 문제가 제기 될 수 있 다. 따라서 후속연구에서는 표집 지역, 연구대상을 확대 하여 비교·분석하는 포괄적인 연구가 필요하다. 
둘째, 생활무용 참여 종목을 여가로써의 순수무용(한 국무용, 발레, 현대), 라인댄스, 방송댄스로 한정하였기 에 연구에서 제시된 결과를 생활무용 전체로 일반화 시키 는데 한계가 있다. 따라서 후속연구에서는 보다 다양한 생활무용 종목의 선정 및 종목의 특성을 고려한 구체적인 연구가 필요하다.

셋째, 체험경제이론에 따른 체험요인, 스포츠가치관, 지속적 참여의도라는 변수 안에는 본 연구에서 사용된 요 인 이외에도 눈으로 측정 불가한 다양한 상호작용 요소들 이 작용한다. 따라서 후속 연구에서는 참여관찰, 인터뷰 법 등의 연구방법을 활용하여 대상자의 내면적인 부분까 지 접근 가능한 심도 깊은 연구가 병행되어야 할 것이다.

\section{참고문헌}

Ahn, C. (1999). A research of sport consumer behavior and the study of interrelationship with sport socialization. Journal of physical education, 38(3), 165-174.

Allport, G. \& Lindzey, G. (1960). Study of Values. Boston: Houghton Mifflin.

Bagozzi, R. \& Dholakia, U. (2002). Intentional social action in virtual communities. Journal of Interactive Marketing, 16(2), 2-21.

Beardsley, M. (1960). Aesthetics Experience Regained. Journal of Aesthetics \& Art Criticism. Fall. 3-11.

Cho, M. (2011). Impact of Game Commitment on Sport Values and Attitude in Female Soccer Players. Master. Dissertation, Graduate School of Education Woosuk University.

Choi, D. \& Kim, H. \& Kim, J. (2000). A Cognitive and Emotional Strategy for Computer Game Design. Asia Pacific Journal of Information Systems, 10(1), 165-187.

Choi, H. (2017). A Study on the Effects of Life Satisfaction on Mental Health and Stress of Married Women Participating in Sports for All. Master. Dissertation, Graduate School of Education KyungHee University.

Choi, W. (2013). The Effects of Sports Participation on View of Sports Value and Attitude of University Students. Master. Dissertation, Graduate School of Education Gyonggi University.
Choi, Y. (2013). The effects of experience factors (4Es) of the farming village experience program on the visiting values and the intention of action. Master. Dissertation, Graduate School of Kyungsung University.

Chung, K. \& Yu, K. (2006). The types of the personalities of sports brands and the effects that can be caused by those types on the characteristic factors of consumer and products. Journal of Korean Society For Sport Management, 11(1), 77-87.

Evarett. (1962). On the theory of social change: H ow economic growth begins. Homewood. IL: Dorsey press.

Fornell, C., \& Larcker, D. (1981). Evaluating structural equation models with unobservable variables and measurement error. Journal of marketing research, 39-50.

Gumbrecht. (2008). Fascination and enthusiasm. Seoul: Stone pillows.

Ha, D. (2011). The Effects of Tourist Destination`s Experiential Marketing on Experiential Quality. Journal of Photographic Geography Society, 21(2), 1-5.

Han, H. (2010). he Influence Enjoyment and Flow Experience on Continuos Intentions of Female Dance for all Participants. Journal of Korean Society of Dance Science, 22, 1-16.

Han, S. \& Um, S. (2000). Verification on Experience Realms of Pine and Gilmore: The Case of Participants' Satisfaction of Experiential Activities at Hansan Ramie Festival. Journal of Tourism Organization, 29(2), 131-148.

Hoch. S. (2002). Product Experience is Seductive. Journal of Consumer Research, 29(3), 448-454.

Hong, S. (2010). The Influences of Sports Experiential Elements on Sponsorship Effects. Ph.D. Dissertation, Graduate School of Chosun University.

Hyeon, S. (2006). A Study of the University Student 's Perception About Dancesport. Ph.D. Dissertation, Graduate School of Dongduk Women's University.

Hwang, J. \& Park, S. (2016). A Study on The Experience Economy Based on The Golf Tournament Spectators' Characteristics. Journal of Hotel Management Studies, 25(7), 71-83.

Jang, H. \& Kim, D. (2015). The Relationship among of Participation Motivation of Water Leisure Sports, Selection Attributes and Repurchase Behaviors. Journal of Sport and Leisure Studies, 54(4), 427-437.

Ji, M. (2013). An experiential approach to the horse racing gambling. Master. Dissertation, Graduate School of Sookmyung Women's University. 
Jung, Y. (1997). The Influence of sport participation motivation, arousal seeking and affects on the behavior of sport commitment. Ph.D. Dissertation, Graduate School of Pusan University.

Jung, Y. \& Kwak, H. \& Lee, J. (2012). The Relationship Among the Athletes Coach's Leadership Types, Sport Value and Exercise Adherence Questionnaire of Athletes Players. Journal of Society of Sport, 10(4), 23-26.

Kim, B. (2012). Effects of Involvement of Winter Leisure Sport on flow and Sport Values among University Students. Journal of Society for Sports Science, 21(2), 533-545.

Kim, B. \& Sung, C. (1996). Sources of Enjoyment in Competitive Youth Sport in Korea. Journal of Society of Sport Psychology, 10(2), 193-210.

Kim, C. (2017). AStudy on the Effects of Experiential Marketing on Satisfaction, Behavioral Loyalty and Purchase Intentions. $\mathrm{Ph} . D$. Dissertation, Graduate School of Dankook University.

Kim, D. (2011). The Effects of the Flow Experience of Middle-aged Female Members of Fitness Club On the Physical Self-Efficacy and Sports Values. Master. Dissertation, Graduate School of Daejeon University.

Kim, E. (2015). A Phenomenological Study on the Experience of high school student's participating in a school sport club basketball. Master. Dissertation, Graduate School of Gachon University.

Kwon, H. (2019). A Structure of Aesthetic Experience in Taekwondo Revolution Kick Practitioner. The Korean Journal of Sport, 17(4), 1373-1381.

Kim, H. (2012). The influence of Sensation Seeking of Leisure Dance Participants on Dance Commitment and Addiction to Dance. Master. Dissertation, Graduate School of Education Kyung Hee University.

Kim, J. \& Kim, H. (2010). A Study on the Relations among Experience Element, Pleasure, Satisfaction and Behavioral Intention of Hotel Package Product. Journal of Society for Consumer Culture, 13(1), 39-60.

Kim, K. (2010). AMOS 18.0 Structural Equilibrium Model Analysis. Seoul: Hannah.

Kim M. \& Kang, I. (2007). The Impacts of the Popular Korean Wave on the Korean Tourist Destination Image, Tourists' Satisfaction and Behavioral Intention. The Journal of Korea Tourism Management, 22(3), 359-381.

Kim, Y. (2013). An Analysis of the Relation among Amusement
Factor over Sports-for-all Participation, Satisfaction with Lesson and Sports Continuance Intention. Journal of Sports Science, 12(3), 201-210.

Kim, Y. (2013). The Effects of the Flow Experience of Old Woman Members of Fitness Club On the Physical Self-Efficacy and Sports Values. Learner-centered Education Society, 3, 445-462.

Kwon, Y. (2014). Relationship between marine Sports Participants' Experiences, Life Satisfaction and Decision Behavior.Master. Dissertation, Graduate School of Information industry Hanseo University.

Kwon, W. \& Kim. K. (2018). Applying Experience Economy Theory to Sport Spectatorship: The Relationship Analysis among Stadium Experiences, Satisfaction, Revisit Intention to Professional Baseball Game. The Korean Journal of Physical Education Studies, 57(2), 303-317.

Hawang, k. (2007). Effects of participant motivation on exercise commitment and job satisfaction in Inlin skater. Master. Dissertation, Graduate School of Dankook University.

Hosany, S., \& Witham, M. (2010). Dimensions of cruisers' experiences, satisfaction, \& intention to recommend, Journal of Travel Research, 49(3), 351-364.

Lee, H. (2009). The research for the relationship between women experiences of migrant women in multi-cultural families and improving social adaptability : around a model dance class of Busan Yeungjin general social welfare center. Master. Dissertation, Graduate School of Education Kyungsung University.

Lee, H. (2014). Impact of physical activity level and types of activities of middle-aged women on risk factors of metabolic syndrome and energy metabolism. Ph.D. Dissertation, Graduate School of Education Yong-In University.

Lee, J. (2011). A Study on the Determinants of Customer Service and Recognition in Sports Products Business. Korea Wellness Society, 6(2), 125-138.

Lee, J. \& Jeong, S. \& Ko, Y. (2013). Market Segmentation by Characteristics, View of Sports Values, Sports Consumer Culture and Sports Attitude of the World Cup Street Cheering Participants. Journal of Physical Science Research Society, 24(1), 86-104.

Lee, J. \& Kim, H. \& Kim, J. (2017). The Structural Relationship among Water Park Experience factor, Enjoyment, Brand Loyalty and Relational Continuance Intention based on 
Experience Economy. Korean Society of Physical Education, 26(5), 729-743.

Lee, J. (2015). The Influence of Tournament Experience in Golf Gallery on Pleasure, Satisfaction, and Re-spectating Intention: Focus on the Experience Economy Theory. Master. Dissertation, Graduate School of Seoul National University.

Lee, J. \& Song, H. \& Lee, C. (2011). A Study on The Experience, Experiential Value, and Satisfaction of 3D Film Based on The Pine and Gilmore's Experience Economy Theory: The Case of The Film' Avatar'. The Korea Tourism and Leisure Society, 23(5), 281-298.

Lee, K. (2011). The Relationship between Marine Sports Value and Perception of Elementary and Middle School Participants in Marine Sports. Korean Journal of Sociology of Sport, 24(1), 25-40.

Lee, K. \& Yoon, Y. \& Kim, H. (2011). The effects of flow experience of marine-Leisure sport on sport values and Leisure attitude among middle school students. Journal of leisure and recreation studies, 35(4), 99-111.

Lee, S. \& Sun. J. (2016). A Study on the Relationship among Tourism Experience, Brand Value, Congruity and Loyalty of Local Festival: A Case of Gagopa Chrysanthemum Festival. International Journal of Tourism and Hospitality Research, 30(1), 5-20.

Lee, S. (2007). Aesthetic View on the Physical Culture of Ancient Greece. Ph.D. Dissertation, Graduate School of Korea National Sport University.

Lee, Y. (2001). The Effects of Married Women's Dance Participation on Life Satisfaction. Master. Dissertation, Graduate School of Dankook University.

Lee Y. \&. Yu, B. (2015). The Effects of Experiential Factors on Festival, Enjoyment, Satisfaction and Behavioral Intention: An Application of Korea Wine Festival. The Korea Academic Society Of Tourism And Leisure, 27(1), 271-290.

Lee, W. \& Pham, H. \& Seo, M. (2016). The Effects of the Vietnamese Tourist Travel Experience Elements on value, Satisfaction and Loyalty. Journal of Food Service Industry, 12(1), 107-116.

Leonard. (1980). A Sociological perspective of sport.

Lim, B. (2010). A Sport Sociological Interpretation of Experiences in Outdoor Adventure Leisure Sports: Focused on Phenomenological Approach. Ph.D. Dissertation, Graduate School of Korea National Sport University.
Lim, M. \& Lee, S. (2019). The Effect of Marine Sports Event Experience on Visitor's Satisfaction and Behavior Intention. Journal of Product Research, 37(3), 121-127.

Lim, S. (2018). The Relationship on Sport Values and Continuous Participation Intention of the Dance for All Participants according to Experience Economics Theory : Focused on the Aesthetic Understanding in Sports. Ph.D. Dissertation, Graduate School of KyungHee University.

McDoWell, C. (1984). Leisure: Conscious- ness, Well-being, and Counseling. IL: Charles C Thomas Pub.

Myoung, Y. (2017). A Study on Temple Stay about Satisfaction in Experience Economy-The Mediating Effects of Perceived value, Reliability and Flow. Ph.D. Dissertation, Graduate School of Sejong University.

Oh H, Fiore, A., \& Jeoung, M. (2007). Measuring Experience Economy Concepts: Tourism Applications, Journal of Travel Research, 46(2), 119-132.

Oh, I. (2011). Study on the Service Quality Satisfaction of Public Sport Facilities on Consumers' Intention of Repurchase and Oral Propagation. Journal of sport research, 40(2), 449-458.

Oh, J. (2000). The effects of sports participation on view of sports value and attitude of university students. Ph.D. Dissertation, Graduate School of Dong-A University.

Park, J. (2002). A Study on the Women's Special Hospital Service Quality and Customer Satisfaction. Ph.D. Dissertation, Graduate School of Gyonggi University.

Park, J. (2019). The Effect of Pro-baseball Spectator's Experience on Value, Satisfaction and Behavioral Intention: Focus on the Theory of Experience Economy. Master. Dissertation, Graduate School Eulji University.

Park, M. \& Lee, J. (2008). The Effect of Old People`s Engagement in Practical Dance on their Health Awareness and Life Quality. Journal of Sport and Leisure Studies, 33(1), 705-714.

Park, S. \& Hae, H. (2016). The Influence of Education Type and Enjoyment on Continuous Intentions of Female Dance for All Participants. Journal of Dance Society, 33(1), 11-22.

Pine, B. \& Gilmore, J. (1998). Welcome to the Experience Economy. Harvard Business Review, 76(4), 96-105.

Scanlan, T. \& Simons, J. (1992). The construct of sport enjoyment. Motivation in sport and exercise, 199-215.

Schmitt, B. (1999). Experiential marketing. Journal of marketing management, 15(1-3), 53-67.

Seo, M. (2012). Astudy on the effect of experience on participants' 
emotion, memory, satisfaction, and loyalty in marine leisure sports. Ph.D. Dissertation, Graduate School of Sejong University.

Sung, H. (2016). The Relationships among Sports Club Participation Flow, Sport Value, and Future Intention to Participate in Sports of Middle School Students. Master. Dissertation, Graduate School of Education KyungHee University.

Shin, H. \& Park, M. (2007). The Relations between Dancers`Sense of Achievement in Performance and Commitment to Audience. Journal of Dance Society, 60, 191-204.

Shim, M. (2013). The effects of involvement and type of experience on the post-experience emotion and behavioral intention of participants: Focusing on sailing yacht. Ph.D. Dissertation, Dong-A University.

Shim, S. (2017). Affect of satisfaction with marine leisure sport experience on marine leisure sport image and participation intention. Master. Dissertation, Korea Sports University.

Shim, Y. \& Oh, K. (2014). The Influence of Leisure Awareness on Leisure Commitment and Sports Value among Secondary School Students Who Participate in After-School Activities. Journal of physical education, 53(1), 171-130.

Song, H. \& Choi, Y. \& Lee, C. (2011). A Study of Festival Visitors's Loyalty based on Experience Economy :The Case of Boryeong Mud Festival. Journal of Society for Sustainable Tourism, 25(6), 179-199.

Song, H. \& Lee, C. (2015). The Influence of Temple Stay Experience on forming Visitor's Behavioral Intention: Focused on Experience Economy. Theory, Journal of Philosophy of Movement, 9(1), 13-25.
Song, H. \& Lee, C. \& Park, J. \& Hwang, Y. \& Reisinger, Y. (2015). The influence of tourist experience on perceived value \& satisfaction with temple stays, The experience economy theory. Journal of Travel \& Tourism Marketing, 32(4), 401-415.

Sports and Tourism (2009). Athletic white paper.

Sports and Tourism (2018). Report on the Actual Condition of Participation in Physical Activity in National Life.

Sung, H. (2016). The Relationships among Sports Club Participation Flow, Sport Value, and Future Intention to Participate in Sports of Middle School Students. Master. Dissertation, Graduate School of Education Kyung Hee University.

Whang, I. \& Hwang, Y. \& Na, K. (2014). The Influences of Sports Experiential Elements on Sponsorship Effect. Journal of Industrial Economics and Business 27(1), 537-564.

You, G. \& Park, Y. \& Lee, H. (2015). Study on effect of Regional Image and Trust on festival visitor's satisfaction based on experience economy theory: Focusing on Yangyang Songi festival. Journal of Korea Tourism \& Leisure, 27(7), 299-317.

Youm, G. (2008). The Influences of Self-Management once Flowof Performance in College Dancer's. Journal of Dance, 55, 215-231.

Yoo, I. (2010). Dance wind blowing in life sports. Sports Seou

Yoo, J. (2011). The Relationship among enjoyment, flow experience and continuous intention of women's participation in dance for all. Master. Dissertation, Graduate School of Kyung Hee University.

You, S. \& Jeon, H. (2016). A Study of Intention to Revisit Jeonju Hanok Village associated with Consumer Experience. The Korean Society of Community Living Science 27(1), 121-136. 


\section{체험경제이론에 따른 생활무용참여자의 스포츠가치관, 지속적 참여의도의 구조적 관계 \\ 이정학 ${ }^{1}$, 임선영 ${ }^{2}$ \\ 1경희대학교 체육대학 교수 \\ 2경희대학교 체육학 박사}

〔목적〕 본 연구는 체험경제이론에 따른 생활무용참여자의 스포츠가치관 및 지속적 참여의도의 영향관계를 규명하는데 그 목적이 있다. 〔방법) 총 475부의 설문 자료를 사용하였으며, 자료처리방법으로는 SPSS 21.0 과 AMOS 18.0을 이용하여 빈도분석, 상관관계분석, 확인적 요인분석, 구조방정식모형분석을 실시하였다. 〔결과〕 첫째, 오락적 체험은 스포츠가치관의 모든 요인에 유의한 영향을 미치는 것으로 나타났다. 둘째, 교육 적 체험은 오락적 가치를 제외한 모든 요인에 유의한 영향을 미치는 것으로 나타났다. 셋째, 일탈적 체험은 신체적 가치를 제외한 모든 요인에 유의한 영향을 미치는 것으로 나타났다. 넷째, 미적 체험은 스포츠가치관의 모든 요인에 유의한 영향을 미치는 것으로 나타났다. 다섯째, 사회적 가치와 오락적 가치는 지속적 참여의도에 유의한 영향을 미치는 것으로 나타났다. 여섯째, 오락적 체험과 미적 체험은 지속적 참여의도에 유의한 영향을 미치는 것으로 나타났다. ‘결론〕 본 연구의 결과는 체험경제이론의 오락적 체험, 교육적 체험, 일탈적 체험, 미적 체험이 생활무용참여자의 긍정적 스포츠가치관 형성과 지속적 참여의도를 유발할 수 있다는 것을 시사하 며, 생활무용 프로그램 개발 및 운영전략을 위한 기초자료를 제공하여 생활무용 프로그램 전반의 개선과 향상 에 도움이 될 것으로 사료된다.

주요어: 체험경제이론, 생활무용, 스포츠가치관, 지속적 참여의도 